\title{
Late Cretaceous dwarf decapods from Guerrero, southern Mexico and their migration patterns
}

\author{
René H.B. Fraaije ${ }^{1}$, Francisco J. Vega ${ }^{2}$, Barry W.M. van Bakel ${ }^{1}$ and Luis M. Garibay-Romero ${ }^{2,3}$
}

${ }^{1}$ Oertijdmuseum De Groene Poort, Bosscheweg 80, NL-5283 WB Boxtel, The Netherlands, E-mail: info@ oertijdmuseum.nl; ${ }^{2}$ Instituto de Geología, Universidad Nacional Autónoma de México, Ciudad Universitaria, 04510, México, D. F., México, E-mail: vegver@servidor.unam.mx; ${ }^{3}$ Unidad Académica de Ciencias de la Tierra, Universidad Autónoma de Guerrero, Ex Hacienda de San Juan Bautista, 40200, Taxco el Viejo, Guerrero, México

Key words: Dwarfism, decapoda, Cretaceous, new species, Mexico

\begin{abstract}
Two new brachyuran species are described for the Upper Cretaceous Mexcala Formation, Guerrero State, Mexico. Longusorbis quadratus new species (Coniacian, Temalac region) is the oldest and southernmost record for the genus. Xanthosia zoquiapensis new species (Campanian, Zoquiapa region) is the first record for the genus in Mexico. In addition, the age for Costacopluma bishopi Vega and Feldmann is discussed (Coniacian, Temalac region) and represents the oldest and southernmost record for Cretaceous representatives of this genus in North America. All specimens are considerably smaller compared to other species of the same genera and are interpreted as the first example of brachyuran dwarfism in the geological record. These species add new insight into possible migratory routes during the Late Cretaceous. Within Longusorbis, a northwestern migratory route is documented from the Coniacian in Mexico to the Campanian - Maastrichtian of the west coast of North America (Canada), whereas within the genus Xanthosia, a western migratory route from the Albian of Europe to the Campanian of Mexico is indicated. Costacopluma migrated east and north to the west coast of Africa, southeast North America and Greenland.
\end{abstract}

\section{Contents}

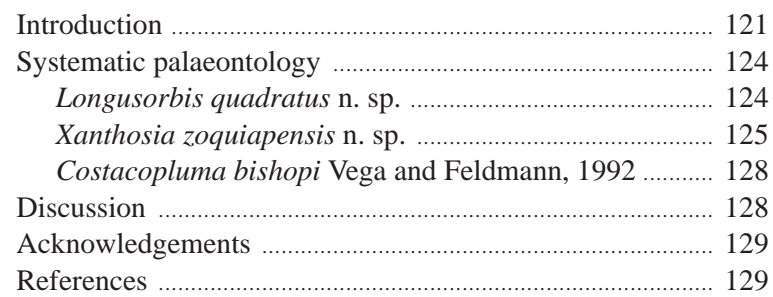

\section{Introduction}

The Mexcala Formation crops out in southern Mexico. It is reported from the states of Puebla, Morelos and Guerrero. This lithostratigraphic unit is a complex sedimentary sequence, as it includes deep-water facies as well as very shallow marine sediments, with lateral and vertical changes, overlying Lower Cretaceous limestones of the Morelos Formation. Defined by Fries (1960) as a 1,220 m flysh-like sequence of pelagic limestones and marls at its base, the Mexcala Formation grades upward to shales, siltstones, sandstones, and conglomeratic lenses. An early Coniacian age was proposed by BohnenbergThomas (1955) for the Mexcala Formation. Cserna (1965) named, described, and interpreted the lithological units in the area. More recent stratigraphic reports have detailed facies distribution, sedimentology, diagenesis, and subdivided the formation into members (Ontiveros-Tarango, 1973; Cserna et al., 1980; Ortega-Gutierrez, 1980; González-Pacheco, 1988; Hernández-Romano et al., 1998; HernándezRomano, 1999, among others). Most authors agree that deposition of the first sediments of the Mexcala Formation occured in Turonian times, while the last marine deposits are found in late Maastrichtian siltstones and sandstones of the study area (Alencáster, 1980; Perrilliat et al., 2000).

Fossil content of the Mexcala Formation includes foraminifera (Hernández-Romano et al., 1997; Lang 


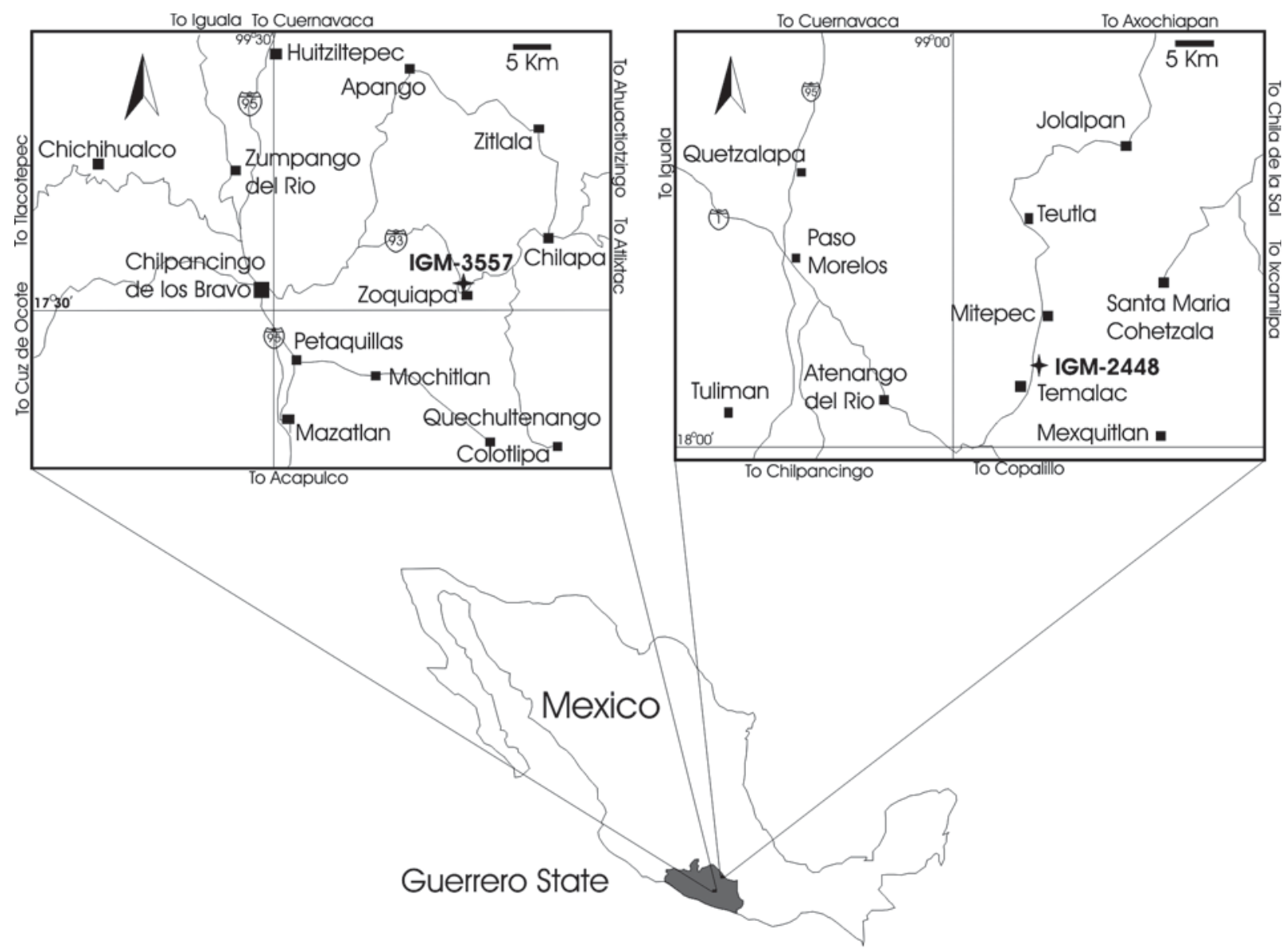

Fig. 1. Location map of the two studied localities in northeast Guerrero state, Southern Mexico.

and Frerichs, 1998; Aguilera-Franco, 2000; 2003; Aguilera-Franco et al., 2001; Aguilera-Franco and Hernández-Romano, 2004; Aguilera-Franco and Allison, 2005), gastropods and bivalves (Böse, 1923; Alencáster, 1980; Alencáster et al., 1987; Perrilliat and Vega, 1996; 2001; Garibay-Romero et al., 1998; 2002; Kiel et al., 2000; 2002; Perrilliat et al., 2000; Kiel and Perrilliat, 2001; 2004; Reyes-Prieto, 2004; Vermeij et al., 2004); ammonoids (Burckhard, 1919; González-Arreola, 1977); crustaceans (Vega and Feldmann, 1992); sea urchins and planktic crinoids (Barrios-Matías, 1992; Sánchez-Rodríguez, 1997; Rosendo-Brito et al., 2002); fishes (Garibay-Romero and Alvarado-Ortega, 2004; Alvarado-Ortega et al., 2004, and dinosaur ichnites (Ferrusquía-Villafranca et al., 1993).

The brachyuran decapods described herein were collected at two localities of the Mexcala Forma- tion in Guerrero. Locality IGM-2448 is found 5 $\mathrm{km}$ north of Temalac, a small village located $35 \mathrm{~km}$ southeast of Iguala, Guerrero. Locality IGM-3557 is found near the town of Zoquiapa, northeast Guerrero (Fig. 1).

Vega and Feldmann (1992) described Costacopluma bishopi based on very small specimens found on light-brown siltstones of locality IGM-2448. They proposed a Maastrichtian age for these sediments, but from recent studies on foraminifera and rudists it is now clear that the age is Coniacian. Although no complete section was measured due to intense folding and covered outcrops, a composite column of $25 \mathrm{~m}$ of limestones, siltstones and sandstones has been constructed (Fig. 2). The base of this sequence is represented by an alternation of dark-brown limestones and light-brown siltstones and mudstones, with a rich content of fossils (fo- 


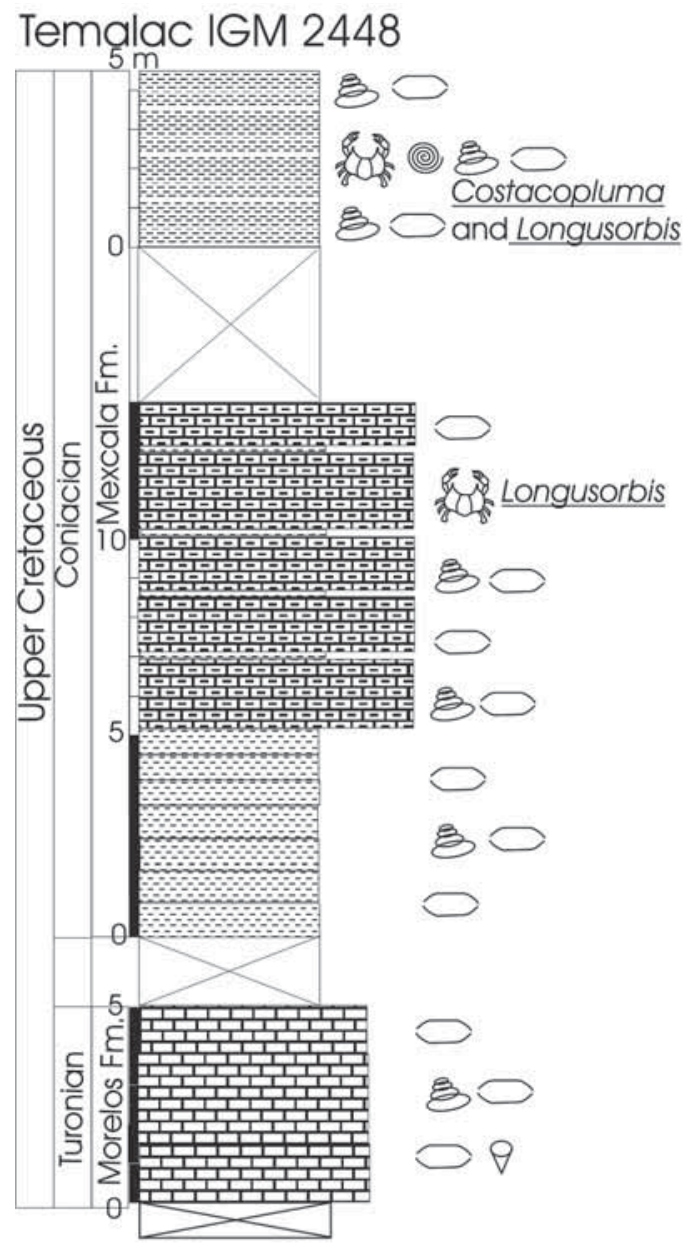

raminifera, rudists, ostreids, echinoids and plant remains). This locality is interpreted to be the transitional contact between the Morelos and Mexcala formations, marking the first pulses of terrigenous sediments. Some well-preserved rudists are found on limestone layers of the Morelos Formation at the base of the section, and belong to the genus Toucasia, of possible Turonian age. Based on foraminifera studies, Lang and Frerichs (1998) proposed a Coniacian age for the first Laramide pulses in the study area, marking as a change in the sedimentary regimen from carbonates to fine siliciclastic sediments. Based on identification of the Dicarinella concavata biozone, Lang and Frerichs (1998) placed the first strata of the Mexcala Formation in the Coniacian just above what they called the Cuautla Formation limestones. An interesting fact is that one of the species here reported, Longusorbis quadratus new spe-
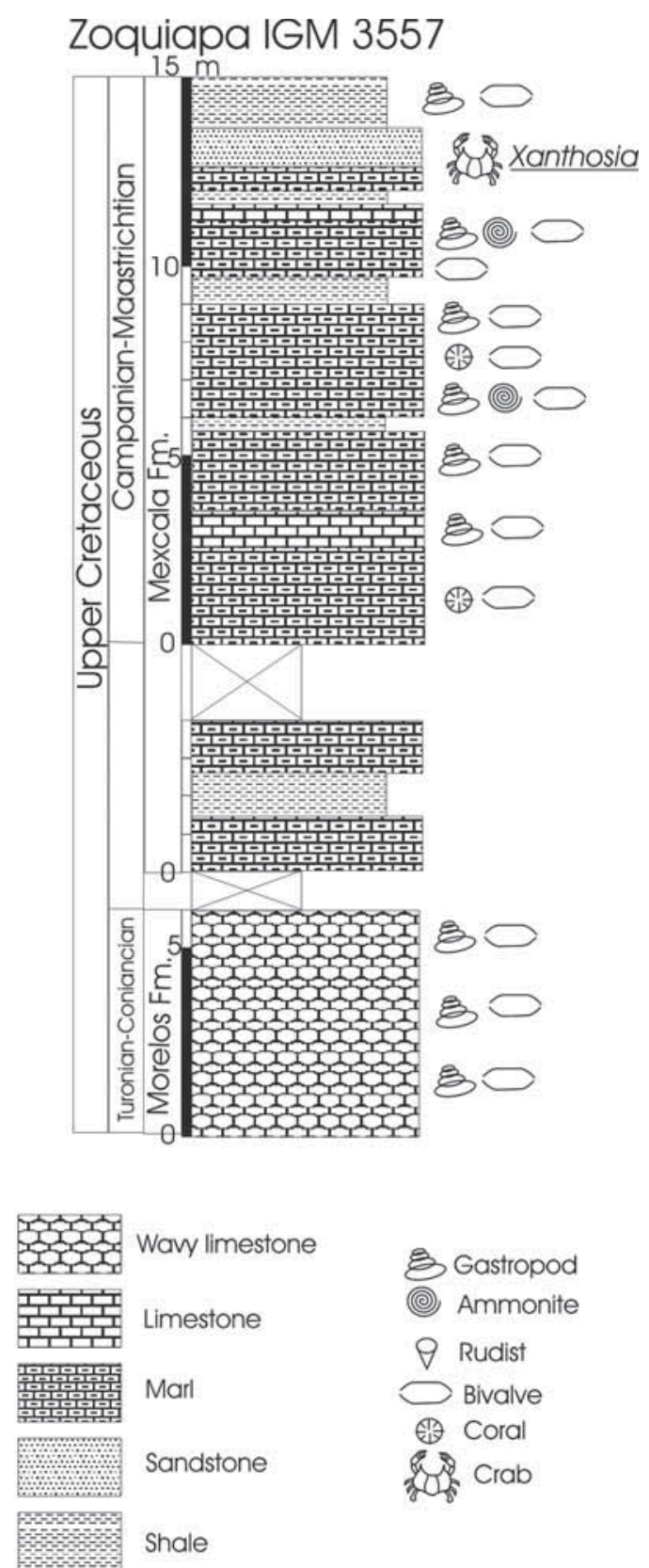

Fig. 2. Composite stratigraphic section at localities IGM-2448 and IGM-3557, showing lithology and thickness of Morelos and Mexcala formations.

cies, was found both in the uppermost limestone layers of the Morelos Formation, and in siltstones of the lower part of the Mexcala Formation. It is important to note that Lang and Frerichs (1998) proposed that the southern margin of the North American Plate in northern Guerrero was isolated 
from the Coniacian-early Santonian Pacific Ocean. However, occurrence of the other representative species of Longusorbis, L. cuniculosus Richards, 1975 in upper Campanian - lower Maastrichtian sediments of the Shelter Point locality at Vancouver Island, Canada (Richards, 1975; Schweitzer et al. 2003), clearly indicates a northwest migration of this genus during the Late Cretaceous. The uppermost part of the Mexcala Formation is represented by siltstones and sandstones of early to late Maastrichtian age in the Temalac - Mitepec area (Perrilliat et al., 2000).

The Mexcala Formation is represented by shallow marine light brown siltstones nearby Zoquiapa town, northeastern Guerrero, where a composite section of $25 \mathrm{~m}$ (Fig. 2) contains several species of gastropods and bivalves of Campanian age.

The material studied is deposited in the Colección Nacional de Paleontología, Instituto de Geología, Universidad Nacional Autónoma de México. Types are included in the Type Collection and classified under the acronym IGM.

\section{Systematic palaeontology}

Order Decapoda Latreille, 1802

Section Heterotremata Guinot, 1977

Superfamily Portunoidea Rafinesque, 1815

Family Carcineretidae Beurlen, 1930

Genus Longusorbis Richards, 1975

Type species. Longusorbis cuniculosus Richards, 1975 by monotypy.

\section{Longusorbis quadratus new species}

Figures 3.1, 3.2, 4.1

Diagnosis. Relatively small Longusorbis, with quadrate carapace, ornamented margins and narrow urogastric region.

Description. Relatively small carapace, quadrate in outline, widest across the anterior third located at the outer orbital spines, weakly convex transversely and longitudinally. Rostrum medially sulcate and downturned, broadly rimmed and bicornate base. Wide orbits cut by two fissures, inner third concave, outer two-third first sinuous ending in a forwardly and outwardly directed, massive outer orbital spine. Including the outer orbital spine, the lateral margin is armed with 4 equally outwardly directed spines decreasing in size posteriorly. Regions are distinct and demarcated by furrows. The anterior process of the relatively small mesogastric region extends almost to the frontal, the distinct top fading into the downturned sulcus of the rostrum. The most prominent furrow is the cervical furrow extending sinuously from the base of the mesogastric lobe ending below the outer orbital spine defining the posterior margin of the swollen protogastric and hepatic regions. The forwardly-directed hepatic furrow separates the protogastric and hepatic regions. The width of the urogastric region is smaller than the maximum width of the mesogastric region. The broad shield shaped cardiac region is separated from the branchial regions by broad shallow furrows. The mesobranchial lobes bear three tubercles forming a triangle. The posterolateral margins are long and converging posteriorly, slightly concave at the probable point of attachment of the fifth pereiopods.

Material. Two specimens. Holotype IGM-8969, and paratype IGM-8970. Coniacian, Mexcala Formation, Temalac, Guerrero.

Measurements. Holotype IGM-8969 length ca. 5.0 $\mathrm{mm}$, width ca. $5.0 \mathrm{~mm}$. Paratype IGM-8970 length ca. $13.0 \mathrm{~mm}$, width ca. $13.8 \mathrm{~mm}$.

Etymology. Refers to carapace outline.

Remarks. This new species differs from L. cuniculosus in having a quadrate outline, a spinose postero-lateral margin, a significantly narrower urogastric region and a more robust front.

This genus migrated at the end of the Cretaceous to the north where, in the late Campanian-early Maastrichtian, the closely related $L$. cuniculosus reaches up to $5 \mathrm{~cm}$ in carapace width (4 times larger than L. quadratus n. sp.) in the Shelter Point locality at Vancouver Island, Canada (Richards, 1975; Schweitzer et al. 2003).

An eastward migration has also to be taken in account considering the close evolutionary relationship with the genus Carcineretes known from the Maastrichtian of SE Mexico, Belize and Jamaica (Vega et al. 1997; 2001). Longusorbis and Carcineretes have 
a very similar quadratic outline, bicornate and downturned rostrum, orbital incisions, carapace groovearrangement and posterior margin morphology.

The genera Withersella, Torynomma and Binkhorstia, all belonging to the Torynommidae (van Bakel et al., 2003), also have very similar to almost identical dorsal carapace morphologies as seen in the carcineretids. Distinction often can only be made on the ventral characters. Torynommidae differ only from the Carcineretidae in having a dorsally orientated, strongly reduced fourth and/or fifth pair of pereiopods, and being much smaller in overall size. Either the Carcineretidae and the Torynommidae are evolutionary very closely related or the dorsal similarities are a matter of convergence. In the first case the Torynommidae should also be placed in the Superfamily Portunoidea. To solve this matter more study and material is needed.

The carcineretids and torynommids, although relatively successful during the Cretaceous, finally didn't cross the K/T boundary. It seems that they couldn't cope with the thinner, more spinose and hexagonal carapaces (better swimming morphology) and much larger orbits (better predatory morphology) of the Late Cretaceous radiating genera like Xanthosia and Cretachlorodius (Fraaye, 1996). Distribution of the two known species of Longusorbis is given in Figure 5.

Section Podotremata Guinot, 1977

Family Etyidae Guinot and Tavares, 2001

Genus Xanthosia Bell, 1863

Type species. Xanthosia gibbosa Bell, 1863 (= Podophthalmus buchii Reuss, 1845) by subsequent designation of Glaessner (1929).

\section{Xanthosia zoquiapensis new species}

Figures 3.3, 3.4, 4.2

Diagnosis. Very small etyid; carapace sub-hexagonal in outline, wider than long; anterolateral margin scalloped and posterior margin convex; front sulcate; orbits very large; orbitofrontal margin more than half total width; prominent sinuous cervical furrow, several branchial furrows.

Description. The carapace is subhexagonal in outline, almost flat longitudinally and gently inclined at the margins transversely, length about two-thirds the width. The frontal area is bilobed and slightly extended beyond the orbits; a deep median sulcus divides around the anterior part of the mesogastric process. The orbits are extremely large, elliptical and outward facing. The rimmed orbital margin bears two short notches. Orbitofrontal margin covers about $70 \%$ the total carapace width. The anterolateral margin is straight starting at the large, blunt outer orbital spine, and regularly divided by four notches. The widest part of the carapace is at the epibranchial angle. The posterolateral margin is clearly convex and indented by a relatively long, frontally directed mesobranchial notch. Carapace separated into distinct regions by shallow groove system. Cervical furrow strongly sinuous. Posterior margin concave, bordered with distinct ridge and about half the total carapace width.

Material. Two internal moulds of carapace. Holotype IGM-8971, and paratype IGM-8972. Campanian, Mexcala Formation, Zoquiapa, Guerrero.

Measurements. Holotype IGM-8971 length ca. 9.0 $\mathrm{mm}$, width ca. $6.0 \mathrm{~mm}$. Paratype IGM-8972 length ca. $9.0 \mathrm{~mm}$, width ca. $7.0 \mathrm{~mm}$.

Etymology. Named after Zoquiapa town, nearby locality IGM-3557.

Remarks. Xanthosia zoquiapensis n. sp. differs clearly from the American Gulf Coast Plain species (Schweitzer Hopkins et al., 1999) in having a much wider orbitofrontal area, a strongly convex posterolateral margin and the absence of granular ornamentation. Concerning groove arrangement, orbit and margin morphologies, $X$. zoquiapensis $\mathrm{n}$. sp. is most closely related to $X$. buchi (Reus, 1845) (Albian-Cenomanian), X. socialis Bakel, Fraaije \& Jagt, 2005 (Campanian) and $X$. semiornata Jagt, Collins \& Fraaye, 1991 (Maastrichtian) all known from NW Europe.

It differs from $X$. buchi and $X$. socialis in having a much more convex posterolateral margin and a shorter and interrupted mesobranchial furrow and from $X$. semiornata in lacking a strong anterior ornamentation. In addition, the new species is stockier than most species of Xanthosia.

Van Bakel et al. (2005) drew attention to a possible westward migration from the possible ancestor 

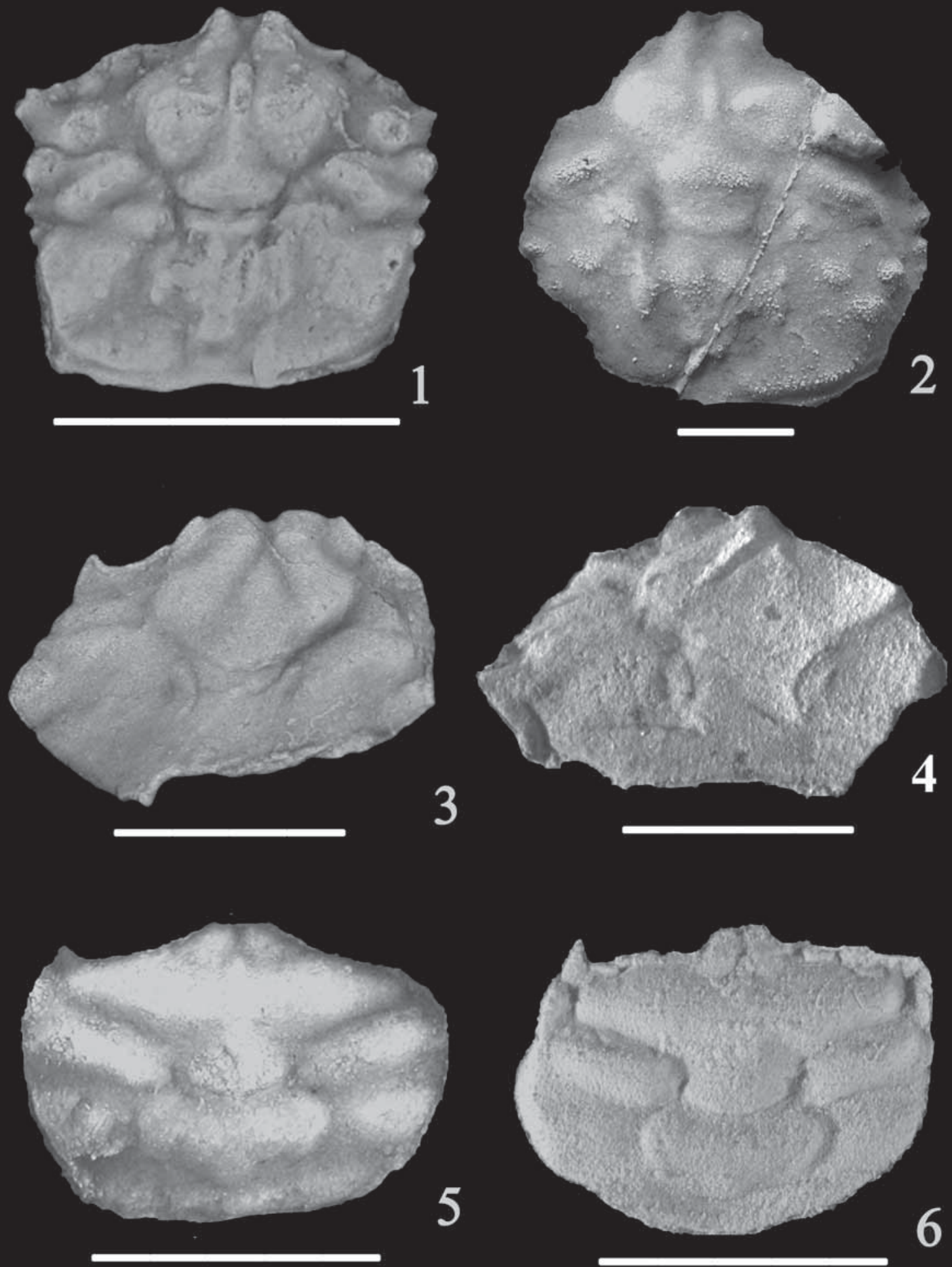

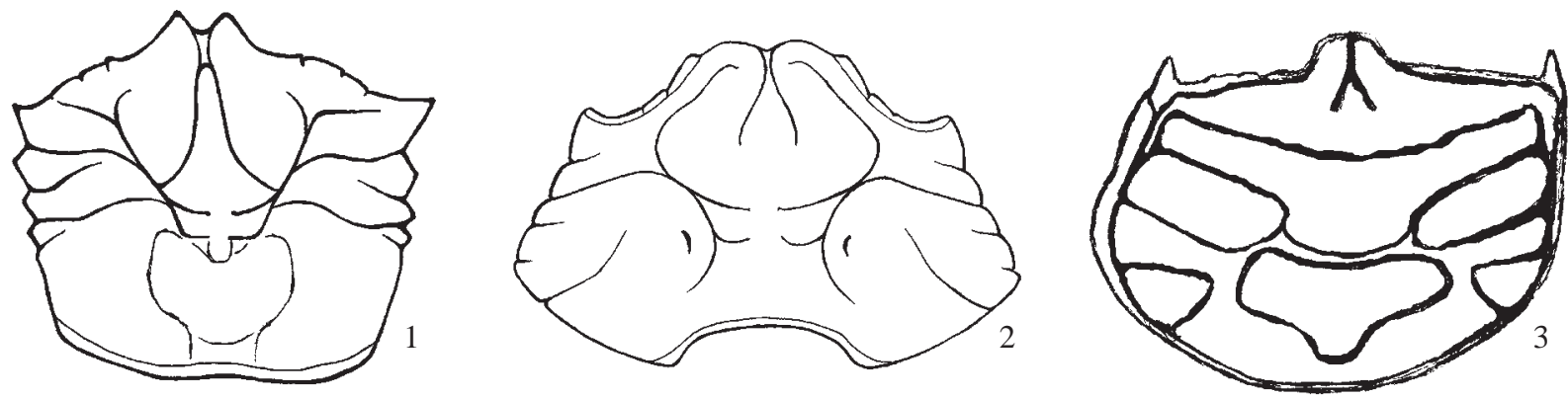

Fig. 4. 1. Reconstruction of Longusorbis quadratus new species. 2. Reconstruction of Xanthosia zoquiapensis new species. 3. Reconstruction of Costacopluma bishopi Vega and Feldmann.
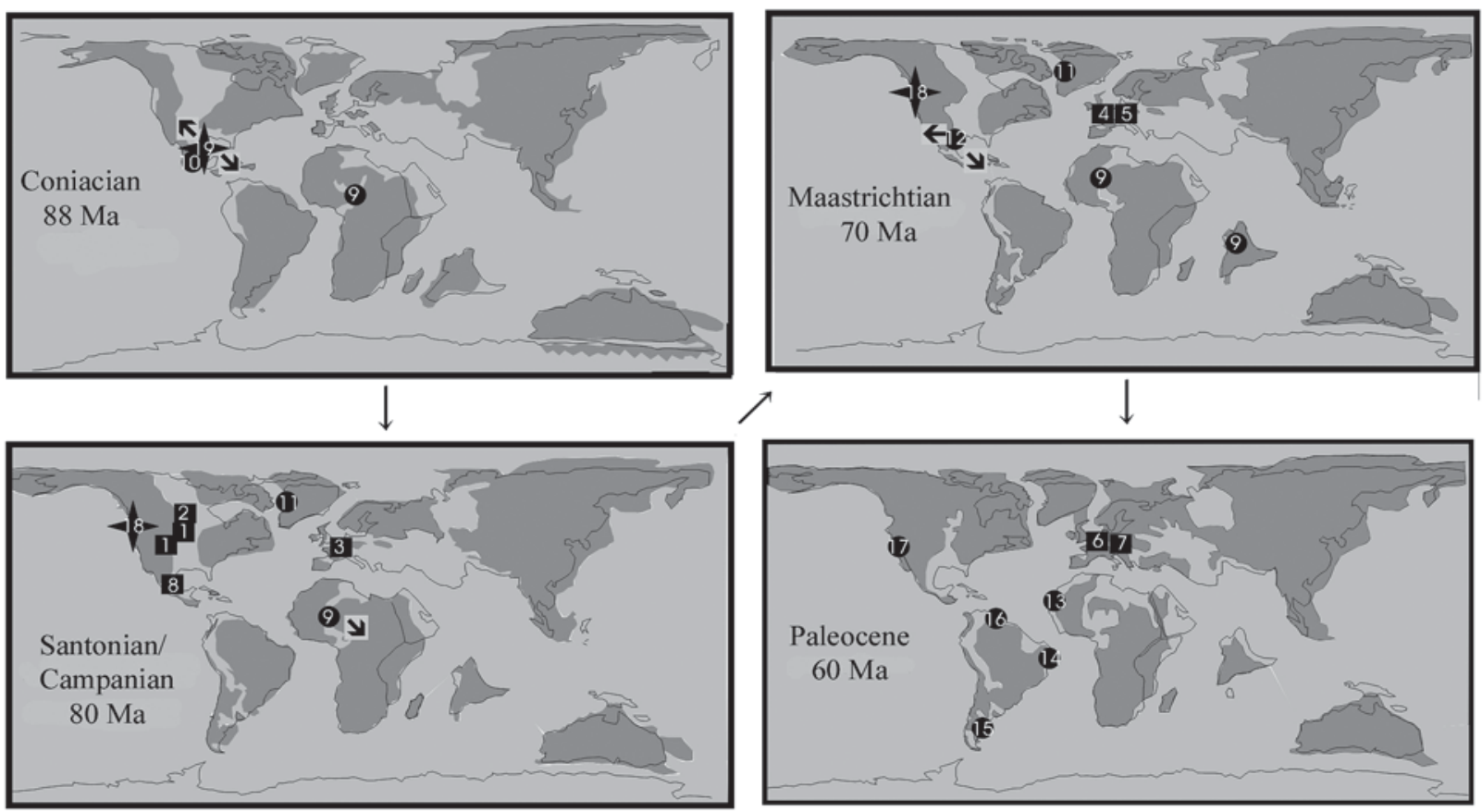

1 Xanthosia elegans

6 Xanthosia gracilis

(11) Costacopluma binodosa

(16) Costacopluma bifida

2 Xanthosia spinosa

7 Xanthosia sp.

(12) Costacop/uma mexicana

(17) Costacop/uma sp.

3 Xanthosia socialis

8 Xanthosia zoquiapensis n. sp.

(13) Costacopluma senegalensis

- Longusorbis cuniculosus

4 Xanthosia delicata

9 Costacopluma concava

(14) Costacopluma nordestina

- Longusorbis quadratus n. sp.

5 Xanthosia semiornata

(10) Costacopluma bishopi

Fig. 3. 1, 2, Longusorbis quadratus new species. 1. Holotype IGM-8969. 2. Paratype IGM-8970. 3, 4, Xanthosia zoquiapensis new species. 3. Holotype IGM-8971. 4. Paratype IGM-8972. 5, 6, Costacopluma bishopi Vega and Feldmann. 5. Paratype IGM8973. 6. Paratype IGM-8974. Scale bars equals $5.0 \mathrm{~mm}$.

Costacopluma salamanca

- Fig. 5. Coniacian - Paleocene paleobiogeographic distribution of brachyuran species of genera present in Temalac and Zoquiapa study areas, Guerrero. Base map modified from Barron, 1981; Dhondt, 1992 and Smith, 1994. Data based on: Collins and Morris, 1975; Richards, 1975; Vega and Perrilliat, 1989; Collins and Rasmussen, 1992; Collins et al., 1994; Feldmann and MatinsNeto, 1995; Vega et al., 1995; Feldmann et al., 1997; Schweitzer et al., 1999; Guinot and Tavares, 2001; Schweitzer et al., 2003; Nyborg et al., 2003; Araujo-Távora and Da Cruz-Miranda, 2004; van Bakel et al., 2005. 
$X$. buchi towards the Campanian species from the American Western Interior and Atlantic Coastal Plain. The occurrence of $X$. zoquiapensis n. sp. in the Campanian of Mexico perfectly fits into this paleomigratory model. Figure 5 illustrates distribution of species of Xanthosia during the Late Cretaceous.

Superfamily Retroplumoidea Gill, 1894

Family Retroplumidae Gill, 1894

Genus Costacopluma Collins and Morris, 1975

Type species. Costacopluma concava Collins and Morris, 1975 by original designation.

Costacopluma bishopi Vega and Feldmann, 1992 Figures 3.5, 3.6, 4.3

Description. Carapace small, ovate in transverse section, widest at level of mesobranchial areas, with three prominent, rounded transverse ridges. Anterolateral margins straight, with a small spine at level of cervical groove; posterolateral margins rounded; posterior margin straight; anterior margin nearly straight, slightly concave above orbits, bordered by two prominent, forward directed spines. Orbits large, rounded. Rostrum prominent, bilobulate. Fused protogastric and mesogastric lobes form anterior transverse ridge, slightly inclined backwards in central part to ovate mesogastric lobe. Cervical groove deep, parallel to protogastric lobes, curved at level of mesobranchial lobes. Second ridge formed by fusion of epibranchial and mesobranchial lobes, of nearly uniform width, inclined posteriorly to base of mesogastric lobe where they become narrower. Posterior ridge formed by metabranchial lobes and cardiac/intestinal regions. Metabranchial lobes perpendicular to carapace length, half as long as epibranchial/mesobranchial lobes. Cardiac region subtrapezoidal, intestinal region narrow at base of cardiac region.

Material. Hypotypes IGM-8973 to IGM-8974.

Measurements. Hypotype IGM-8973 length ca. 6.5 $\mathrm{mm}$, width ca. $7.5 \mathrm{~mm}$. Hypotype IGM-8974 length ca. $6.3 \mathrm{~mm}$, width ca. $9.0 \mathrm{~mm}$.

Remarks. In documenting Costacopluma concava from the Upper Cretaceous of Nigeria, Collins and Morris (1975) mentioned presence of two paratypes from the Coniacian of the Awgu Limestone, Abakaliki Province. However, none of these paratypes is illustrated and although their morphology may resemble Costacopluma, it is not clear if these specimens do belong to this genus. Thus, $C$. bishopi is the first well-documented report for Costacopluma in Coniacian beds and may represent the oldest occurrence of a widely distributed genus during Late Cretaceous - Northeastern Mexico, Greenland, Nigeria, Northern India - (Collins and Morris, 1975; Gaetani et al., 1983; Vega and Perrilliat, 1989; Collins and Rasmussen, 1992; Vega and Feldmann, 1992;), and the Paleocene - California, Venezuela, Senegal, Brazil, Argentina - (Collins et al., 1994; Feldmann and Martins-Neto, 1995; Feldmann et al., 1995; 1997; De Araújo-Távora and Da Cruz-Miranda, 2004; Nyborg et al. 2003) (Fig. 5).

C. binodosa from the upper Campanian of Greenland was described by Collins and Rasmussen, 1992 on the basis of one incomplete specimen. It is larger than $C$. bishopi and bears straight lateral margins.

If the genus raised in America, it must have migrated eastwards to Africa, and northwards to Greenland. African retroplumids also migrated to the east, to reach the north part of India, and by Paleocene times, Costacopluma prevailed in the Paleocene seas of Senegal (Fig. 5). Although abundant in northeastern Mexico during Maastrichtian times, the genus vanished in this area by Paleocene times, and dispersed west to California and south to the north and central parts of South America (Fig. 5).

During Eocene times in Europe, Costacopluma may have given rise to the extant genus Retropluma Gill, 1894 (see Via, 1982), known from deep-water settings of the modern Indopacific sea (Saint Laurent, 1989).

\section{Discussion}

Vega and Feldmann (1992) described Costacopluma bishopi on the basis of eight carapaces. Because of the extremely small size (average width: $4.9 \mathrm{~mm}$ ) of their material, these authors interpreted them as juveniles, yet, at the same time, they also noted overall carapace morphology to be closely similar to adults of the related taxa, Costacopluma mexicana 


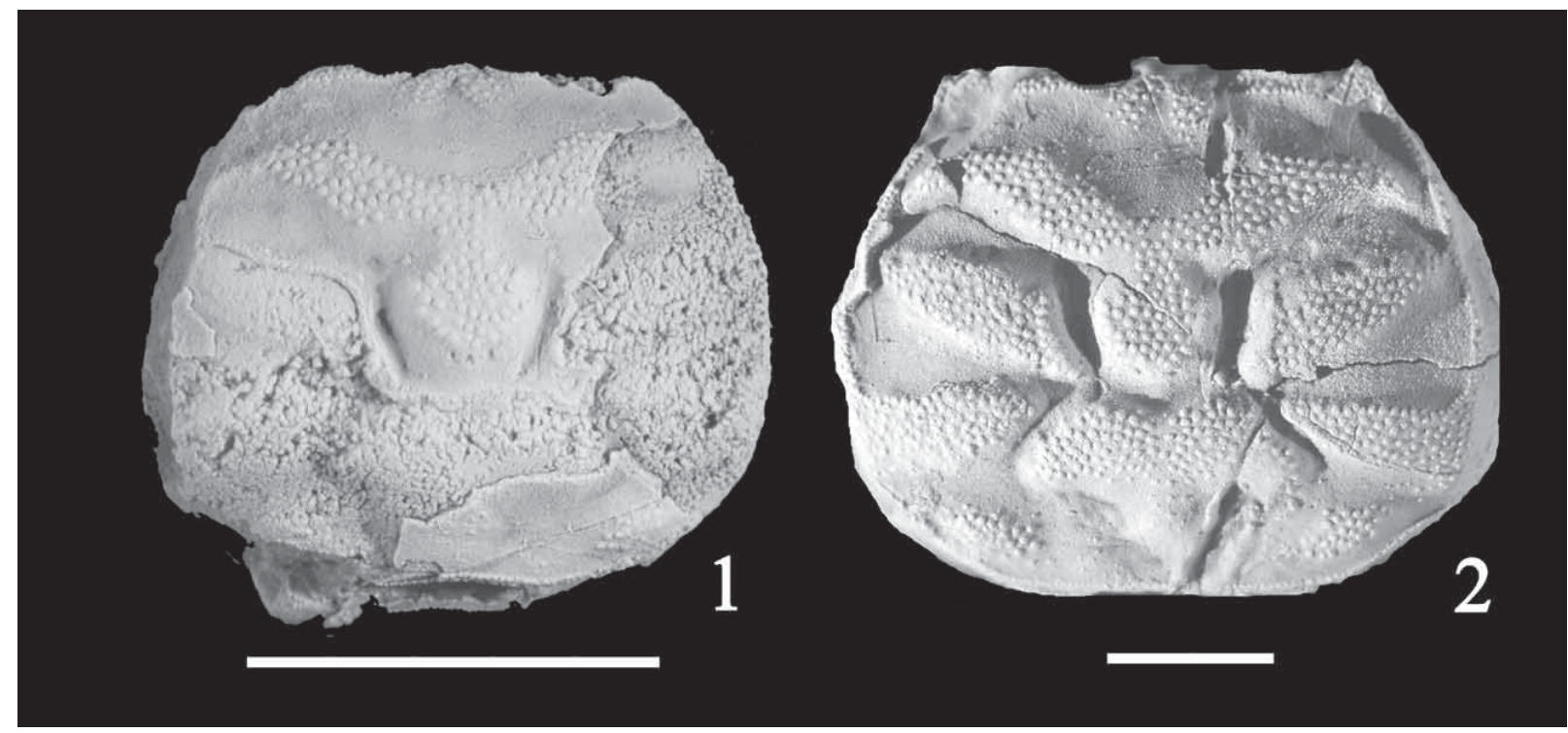

Figure 6. Costacopluma mexicana Vega and Perrilliat, 1989. 1. Juvenile specimen, Maastrichtian, Potrerillos Formation, Nuevo León, northeastern México. 2. Adult specimen, Maastrichtian, Potrerillos Formation, Nuevo León, northeastern México. Scale bars equals $5.0 \mathrm{~mm}$.

and $C$. concava. Comparing the mean carapace width of C. bishopi (ten specimens and four fragmentary carapaces known to date), with that of C. mexicana (numerous specimens known) and $C$. concava (four known specimens) yields ratios of 1:3.5 and ca. 1:4, respectively.

A comparison of average carapace width in Longusorbis quadratus n. sp. and Xanthosia zoquiapensis n. sp. with their closest relatives reveals a striking similarity; that of the former species (two specimens known) is approximately 3.5 times less than of $L$. cuniculosus (numerous specimens available) and that of the latter (two specimens at hand) equals around $30 \%$ of that of $X$. buchi, around $30 \%$ of that of $X$. socialis (a single specimen known) and around $25 \%$ of that of $X$. semiornata (six specimens).

The above-mentioned consistency in width ratios in all three species described, i.e. all being about 3.5 times smaller than their closest relatives, and overall adult carapace morphology (Fig. 6) suggests interpretation of this decapod assemblage as the first example of brachyuran dwarfism in the geological record. The environmental selection to favour this type of dwarfism in this tectonically active basin are still unknown, and further study is needed. Factors such as limited food supply, size-correlated predators and/or strong fluviatile input/admixture inducing brackish waters might be worthwhile pursuing in detail to understand the observed size abnormality.

\section{Acknowledgements}

We thank R.M. Feldmann, D. Guinot, J.W.M Jagt and F. Schram for comments that improved the manuscript and R.M. Feldmann for supplying us an item of literature.

\section{References}

Aguilera-Franco N. 2000. High Resolution Stratigraphy and Palaeoecology of the Cenomanian-Turonian Succession, Southern México: Ph.D. Dissertation, T.H. Huxley School of Environment, Earth Sciences and Engineering, Imperial College of Science Technology and Medicine, University of London, U.K., 244 p.

Aguilera-Franco N. 2003. Cenomanian-Coniacian zonation (foraminifers and calcareous algae) in the Guerrero-Morelos basin, southern Mexico: Revista Mexicana de Ciencias Geológicas 20: 202-222.

Aguilera-Franco N, Allison P. 2005. Events of the CenomanianTuronian Succession, Southern México. Journal of Iberian Geology 31(1): 25-50. 
Aguilera-Franco N, Hernández-Romano U. 2004. CenomanianTuronian facies succession in the Guerrero-Morelos Basin, Southern Mexico. Sedimentary Geology 170: 135-162.

Aguilera-Franco N, Hernández-Romano U, Allison PA. 2001. Biostratigraphy and environmental changes across the Cenomanian-Turonian Boundary, southern Mexico. Journal of South American Earth Sciences 14: 247-255.

Alencáster G. 1980. Moluscos del Maestrichtiano de Temalac, Guerrero. In: Comisión Federal de Electricidad, Libro Guía de la Excursión geológica a la parte central de la cuenca del Alto Balsas, Guerrero y Puebla. III Reunión Nacional de Geotecnia y Geotermia. Sociedad Geológica Mexicana: 39-43.

Alencáster G, Hernández-García R, García-Villegas F. 1987. Rudistas Hipurítidos (Bivalvia-Hippuritacea) del Cretácico Superior de la parte central del Estado de Guerrero: Revista de la Sociedad Mexicana de Paleontología 1: 24-39.

Alvarado-Ortega J, Garibay-Romero LM, Vega FJ. 2004. Rayas fósiles del Cretácico Superior del Estado de Guerrero. In: Resúmenes, IX Congreso Nacional de Paleontología, Sociedad Mexicana de Paleontología, Tuxtla Gutiérrez, Chiapas: 68.

Bakel BWM van, Fraaije RHB, Jagt JWM. 2005. A new late Campanian species of Xanthosia (Crustacea, Brachyura) from northwest Germany. Crustaceana 78: 285-295.

Bakel BWM van, Jagt JWM, Fraaije RHB, Coole Y. 2003. New data on the crab Binkhorstia ubaghsii (Late Maastrichtian; NE Belgium, SE Netherlands). Contributions to Zoology 72: 85-89.

Barrios-Matias S. 1992. Equinoides (Echinodermata-Echinoidea) del Cretácico Superior de Ahuexotitlán, Guerrero; Implicaciones paleogeográficas y paleoecológicas. Unpublished Professional Thesis, Escuela de Ciencias Químico-Biológicas, Universidad Autónoma de Guerrero, 45 p.

Bell T. 1863. A monograph of the fossil malacostracous Crustacea of Great Britain. Part II, Crustacea of the Gault and Greensand: Palaeontographical Society Monograph, viii + 40 pp.

Beurlen K. 1930. Vergleichende Stammesgeschichte, Grundlagen, Methoden, Probleme unter besonderer Berücksichtigung der höherer Krebse. Fortschritte Geologie und Palaeontologie 8: 317-586.

Bohnenberg-Thomas O. 1955. Bosquejo geológico a lo largo de la carretera Iguala-Chilpancingo, Estado de Guerrero. Unpublished Professional Thesis, Facultad de Ingeniería, Universidad Nacional Autónoma de México, 61 p.

Böse E. 1923. Algunas faunas cretácicas de Zacatecas, Durango y Guerrero. Instituto Geológico de México 42: 1-219.

Burckhardt C. 1919-1921. Faunas jurásicas de Simón (Zacatecas) y Faunas cretácicas de Zumpango del Río (Guerrero). Boletín del Instituto Geológico de México 33: 1-136.

Collins JSH, Morris SF. 1975. New crab Costacopluma concava from the Upper Cretaceous of Nigeria. Palaeontology 18: 823-829.

Collins JSH, Rasmussen HW. 1992. Upper Cretaceous - Lower Tertiary decapod crustaceans from West Greenland. Grønlands Geologiske Undersøgelse Bulletin 162: 1-46.

Collins JSH, Higgs R, Cortitula B. 1994. A new crab, Costacopluma bifida (Crustacea, Decapoda) from the Paleocene of Venezuela. Bulletin of the Mizunami Fossil Museum, 21: 29-34.
Cserna Z de. 1965. Reconocimiento geológico en la Sierra Madre del Sur de México, entre Chilpancingo y Acapulco, Estado de Guerrero. Universidad Nacional Autónoma de México, Instituto de Geología Boletín 62: 1-76.

Cserna Z de, Ortega-Gutiérrez F, Palacios-Nieto M. 1980. Reconocimiento geológico de la parte central de la cuenca del alto Río Balsas, Estados de Guerrero y Puebla. Socidad Gelógica Mexicana. Libro-Guía de la excursión geológica a la cuenca del alto Río Balsas, 1-33.

De Araújo-Távora V, Da Cruz-Miranda MC. 2004. Sistemática e tafonomia de uma fáunula de crustáceos decápodes da Formação Maria Farinha (Paleoceno), Estado de Pernanmbuco, Brasil. Revista Brasileira de Paleontologia 7: 45-52.

Feldmann RM, Martins-Neto RG. 1995. Costacopluma nordestiana n. sp. (Decapoda: Retroplumidae) from the Maria Farinha Formation (Paleocene) of Brazil. Journal of Paleontology 69: 610-611.

Feldmann RM, Casadío S, Chirino-Gálvez L, Aguirre-Urreta M. 1995. Fossil decapod crustaceans from the Jagüel and Roca Formations (Maastrichtian - Danian) of the Neuquén Basin, Argentina. Paleontological Society Memoir 42: 1-22.

Feldmann RM, Rodríguez MF, Martínez GA, Aguirre-Urreta M. 1997. Costacopluma salamanca new species (Decapoda, Retroplumidae) from the Salamanca Formation (Danian) of Patagonia, Argentina. Journal of Paleontology 71: 125-130.

Ferrusquía-Villafranca I, Tilton TL, Lang HR, Pittman JG, Lockley M. 1993. Dinosauricnitas tardicretácicas en Puebla suroccidental y su significación geológico-paleontológica, In: IV Congreso Nacional de Paleontología, México, D. F., Resúmenes p. 28.

Fraaye RHB. 1996. Late Cretaceous swimming crabs: radiation, migration, competition, and extinction. Acta Geologica Polonica 46: 269-278.

Fries C. Jr. 1960. Geología del Estado de Morelos y partes adyacentes de México y Guerrero, región central meridional de México. Boletín del Instituto de Geología, Universidad Nacional Autónoma de México 60: 1-236.

Gaetani M, Nicora A, Permoli-Silva I, Fois E, Garzanti E, Tintori A. 1983. Upper Cretaceous and Paleocene in Zanskar Range (NW Himalaya). Rivista Italiana di Paleontologia $i$ Stratigrafia 89: 81-118.

Garibay-Romero LM, Alvarado-Ortega J. 2004. El hallazgo de peces fósiles en el Arroyo "Las Bocas” y la Cantera “Temazol”, Cretácico Superior, en la región norte del Estado de Guerrero. In: Resúmenes, VIII Congreso Nacional de Paleontología, Sociedad Mexicana de Paleontología, Guadalajara, Jalisco, p. 104.

Garibay-Romero LM, Perrilliat MC, Vega FJ. 2002. Moluscos del Cretácico Superior de Ahuexotitlán, Estado de Guerrero. Memory. In: Resúmenes, VIII Congreso Nacional de Paleontología, Sociedad Mexicana de Paleontología, Guadalajara, Jalisco , p. 53.

Gill T. 1894. A new bassalian type of crabs. American Naturalist 28: $1043-1045$.

Glaessner MF. 1929. Crustacea decapoda. In: F.J. Pompeckji (ed.) Fossilium Catalogus. I: Animalia, Pt. 41. W. Junk, Berlin. $464 \mathrm{p}$. 
González-Arreola C. 1977. Amonitas del Coniaciano (Cretácico Superior) de la región de Tepetlapa, Estado de Guerrero. Universidad Nacional Autónoma de México, Revista del Instituto de Geología 1: 167-173.

González-Pacheco VV. 1988. Estratigrafía y condiciones paleoambientales de la Secuencia Cretácica del área de Atenango del Río, Estado de Guerrero. Unpublished Professional Thesis, Facultad de Ingeniería, Universidad Nacional Autónoma de México, 102 p.

Guinot D. 1977. Propositions pour une nouvelle classification des Crustacés Décapodes Brachyuoures. Comptes Rendus Hebdomadaires des Séances de l'Académie des Sciences, séries 3, 285: 1049-1052.

Guinot D, Tavares M. 2001. Une nouvelle famille de Crabes du Crétacé et la notion de Podotremata Guinot, 1977 (Crustacea, Decapoda, Brachyura). Zoosystema 23: 507-546.

Hernández-Romano U. 1995. Evolución sedimentológica de la secuencia cretácica en el área de Huitziltepec, Estado de Guerrero. Unpublished Professional Thesis, Facultad de Ingeniería, Universidad Nacional Autónoma de México, 147 p.

Hernández-Romano U. 1999. Facies, stratigraphy, and diagenesis of the Cenomanian-Turonian of the Guerrero-Morelos Platform, southern México. Unpublished Ph.D. Dissertation, The University of Reading, Postgraduate Research Institute for Sedimentology, $322 \mathrm{p}$.

Hernández-Romano U, Aguilera-Franco N, Buitrón BE. 1998. Late Cenomanian fossil association from Morelos, MexicoStratigraphic implications. Revista Mexicana de Ciencias Geológicas 15: 46-56.

Hernández-Romano U, Aguilera-Franco N, Martínez-Medrano M, Barceló-Duarte J. 1997. Guerrero-Morelos Platform drowning at the Cenomanian-Turonian boundary, Huitziltepec area, Guerrero State, southern Mexico. Cretaceous Research 18: 661-686.

Jagt JWM, Collins JSH, Fraaye RHB. 1991. A new late Maastrichtian xanthid crab from southern Limburg (the Netherlands). Cretaceous Research, 12: 553-560.

Kiel S, Perrilliat MC. 2001. New gastropods from the Maastrichtian of the Mexcala Formation in Guerrero, southern Mexico, part I: Stromboidea. Neues Jarhbuch für Geologie und Paläontologie, Abhandlung 222: 407-426.

Kiel S, Perrilliat MC. 2004. New gastropods from the Maastrichtian of the Mexcala Formation in Guerrero, southern Mexico, part III: higher Caenogastropoda. Neues Jarhbuch für Geologie und Paläontologie, Abhandlung 231: 191-217.

Kiel S, Bandel K, Perrilliat MC. 2002. New gastropods from the Maastrichtian of the Mexcala Formation in Guerrero, southern Mexico, part II: Archaeogastropoda, Neritimorpha and Heterostropha. Neues Jarhbuch für Geologie und Paläontologie, Abhandlung 226: 319-342.

Kiel S, Bandel K, Banjac N, Perrilliat MC. 2000. On Cretaceous Campanilidae (Caenogastropoda, Mollusca). Paläontologie, Stratigraphie, Fazies Heft 8; Freiberger Forschungshefte C 490: $15-26$.

Lang HR, Frerichs WE. 1998. New planktic foraminiferal data documenting Coniacian age for Laramide Orogeny and paleooceanography in Southern Mexico. The Journal of Geology 106: 635-640.
Latreille PA. 1802-1803. Histoire naturelle, générale et particulière, des crustacés et des insectes 3, F. Dufart, Paris. 468 p.

Nyborg TG, Vega FJ, Filkorn HF. 2003. New Late Cretaceous and Early Cenozoic decapod crustaceans from California, USA: implications for the origination of taxa in he eastern North Pacific. Contributions to Zoology 72: 165-168.

Ontiveros-Tarango G. 1973. Estudio estratigráfico de la porción Noroccidental de la Cuenca Guerrero-Morelos. Revista de la Asociación Mexicana de Geológos Petróleros, 25: 189-234.

Ortega-Gutiérrez F. 1980. Rocas volcánicas del Maastrichtiano en el área de San Juan Tetelcingo, Estado de Guerrero. Sociedad Geológica Mexicana. Libro-guía de la excursión geológica a la cuenca del alto Río Balsas, 34-38.

Perrilliat MC, Vega FJ. 1996. A new species of Calyptraphorus (Mesogastropoda: Strombidae) from the Maastrichtian of southern Mexico; some paleobiogeographic and evolutionary implications.Tulane Studies in Geology and Paleontology 29: 119-128.

Perrilliat MC, Vega FJ. 2001. A new Genus and Species of Late Cretaceous Xenophorid Gastropod from Southern Mexico. The Veliger 44: 73-78.

Perrilliat MC, Vega FJ, Corona R. 2000. Early Maastrichtian Mollusca from the Mexcala Formation of the State of Guerrero, southern Mexico. Journal of Paleontology 74: 7-24.

Rafinesque CS. 1815. Analyse de la Nature, ou Tableau de l'Univers et des corps Organisés. Palermo. 224 p.

Reuss AE. 1845. Die Versteinerungen der Bömischen Kreideformation 1. Schweizerbartische, Stuttgart, 58 p.

Reyes-Prieto F. 2004. Patrones originales de coloración en Natícidos del Cretácico Superior de Guerero. Unpublished Professional Thesis, Facultad de Ciencias, Universidad Nacional Autónoma de México, 21 p.

Richards BC. 1975. Longusorbis cuniculosus: a new genus and species of Upper Cretaceous crab; with comments on Spray Formation at Shelter Point, Vancouver Island, British Columbia. Canadian Journal of Earth Sciences 12: 1850-1863.

Rosendo-Brito B, Ernesto-Ocampo Y, Buitrón BE, GaribayRomero LM. 2002. Crinoides planctónicos (Crinoidea, Roveacrinidae) del Cretácico Superior de Cerro Gordo, Municipio de Taxco de Alarcón, Guerrero. In: VIII Congreso Nacional de Paleontología, Guadalajara, Jalisco, Sociedad Mexicana de Paleontología, Libro de resúmenes, p. 79.

Saint Laurent M de. 1989. La nouvelle superfamille des Retroplumoidea Gill, 1894 (Decapoda, Brachyura): systématique, affinités et évolution. Résultats des Campagnes MUSORSTOM, v. 5 (J. Forest, ed.), Mémoires du Muséum national d'Histoire naturelle (A) 144: 103-179.

Sánchez-Rodríguez MA. 1997. Paleobiogeografía de equinoideos del Cretácico Superior (Maastrichtiano) de Nuevo León, San Luis Potosí y Guerrero, con algunas implic aciones medioambientales. Unpublished Professional Thesis, Facultad de Ciencias, Universidad Nacional Autónoma de México, 88 p.

Schweitzer CE, Feldmann RM, Fam J, Hessin WA, Hetrick SW, Nyborg TG, Ross RLM. 2003. Cretaceous and Eocene Decapod Crustaceans from Southern Vancouver Island, British Columbia, Canada. NRC Research Press, Ottawa, Ontario, 66 p. 
Schweitzer-Hopkins C, Salva EW, Feldmann RM. 1999. Reevaluation of the genus Xanthosia Bell, 1863 (Decapoda: Brachyura: Xanthidae) and description of two new species from the Cretaceous of Texas. Journal of Paleontology 73: 77-90.

Vega FJ, Feldmann RM. 1992. Occurrence of Costacopluma (Decapoda: Brachyura: Retroplumidae) in the Maastrichtian of southern Mexico and its paleobiogeographic implications. Annals of Carnegie Museum 61: 133-152.

Vega FJ, Perrilliat MC. 1989. Una especie nueva de cangrejo del género Costacopluma (Crustacea: Decapoda: Retroplumidae) del Maastrichtiano del estado de Nuevo León. Universidad Nacional Autónoma de México, Revista del Instituto de Geología 8: 84-87.

Vega FJ, Feldmann RM, Ocampo AC, Pope KO. 1997. A new species of Late Cretaceous crab (Brachyura: Carcineretidae) from Albion Island, Belize. Journal of Paleontology 71: 615-620.

Vega F J, Feldmann RM, Garcia-Barrera P, Filkorn H, Pimentel F, Avendano J. 2001. Maastrichtian Crustacea (Brachyura: Decapoda) from the Ocozocuatla Formation in Chiapas, southeast Mexico. Journal of Paleontology 75: 319-329.

Vermeij G, Herbert G, Vega FJ, Perrilliat MC. 2004. Mexfusus rotundicostatus, a new genus and species of Neogastropod from the Late Cretaceous of Southern Mexico. Journal of Paleontology 78: 1123-1127.

Via L. 1982. Nueva contribución al estudio paleontolóico de la superfamilia Ocypodoidea (Crustáceos Decápodos). Boletín Geológico y Minero 43: 115-119.

Received: 8 May 2006

Accepted: 4 September 2006 